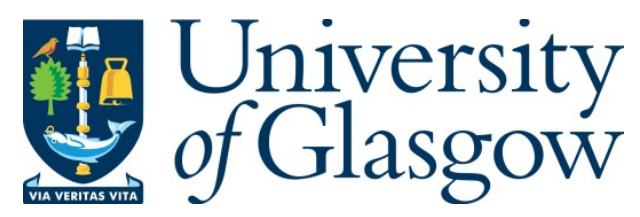

Christelis, D., Dobrescu, L. I. and Motta, A. (2020) Early life conditions and financial risk-taking in older age. Journal of the Economics of Ageing, 17, 100266.

(doi: 10.1016/j.jeoa.2020.100266)

This is the Author Accepted Manuscript.

There may be differences between this version and the published version. You are advised to consult the publisher's version if you wish to cite from it.

https://eprints.gla.ac.uk/216841/

Deposited on: 27 May 2020

Enlighten - Research publications by members of the University of Glasgow http://eprints.gla.ac.uk 


\title{
Early life conditions and financial risk-taking in older age
}

\author{
Dimitris Christelis ${ }^{\mathrm{a}}$ \\ University of Glasgow, CSEF, CFS and Netspar \\ Loretti I. Dobrescu ${ }^{\text {b }}$ \\ University of New South Wales and CEPAR
}

Alberto Motta ${ }^{\mathrm{C}}$

University of New South Wales

May 26, 2020

\begin{abstract}
Using life-history survey data from 11 European countries, we investigate whether childhood conditions - such as socioeconomic status, cognitive abilities and health problems - influence portfolio choice, including home ownership, and risk attitudes later in life. After accounting for the corresponding conditions in adulthood, we find that both higher childhood socioeconomic status and cognition (especially mathematical ability) are strongly and positively associated with owning risky financial assets, a house, as well as with one's willingness to take financial risks. In stark contrast, having had health problems in early life negatively affects only home ownership in older age. Finally, favorable childhood conditions are also positively associated with the transition in and out of risky asset ownership several decades later, both by facilitating investing and making divesting less likely.
\end{abstract}

Keywords: portfolio choice, financial risk, childhood conditions.

JEL Codes: G11, D14, E21, J13, C23, C25

\footnotetext{
a Adam Smith Business School, University of Glasgow. E-mail: dimitris.christelis@glasgow.ac.uk

${ }^{\mathrm{b}}$ Corresponding author. School of Economics, UNSW Business School, University of New South Wales, UNSW Sydney NSW 2052, Australia. E-mail address: dobrescu@unsw.edu.au

c School of Economics, UNSW Business School, University of New South Wales, Australia. E-mail: motta@unsw.edu.au
} 


\section{Introduction}

Why do so very few households invest in risky assets? This puzzle has been preoccupying economists for many years (see e.g., Haliassos and Bertaut, 1995; Guiso, Haliassos, and Jappelli, 2001), with the overwhelming majority of potential explanations related to adulthood. We propose to study this problem from a new angle that has not yet been explored in the literature. ${ }^{1}$ Specifically, we go back in time and examine the effect of childhood conditions on both risky asset choice and risk preferences in older age. To do so, we use micro-survey data that provide both current and retrospective information on a representative sample of people aged 50+ in 11 European countries, with a focus on several childhood indicators related to early cognition, socioeconomic status (SES) and health. The data also contain information on asset choices and risk attitudes at the time of the survey, and thus we can examine how the latter are linked to early life conditions.

We find that risky asset ownership in older age, as well as the willingness to take any financial risks, are strongly and positively associated with childhood SES and cognition. In contrast, the effect of health problems early in life is considerably weaker. Importantly, these results are obtained after controlling for SES, cognition and health status in adulthood, namely by including in our empirical specifications variables such education, wealth, income, and health conditions. Ours is thus evidence for the existence of direct and longstanding (possibly permanent) effects of childhood conditions on economic choices and attitudes later in life, above and beyond their adulthood-related causes. We also further extend the literature on

\footnotetext{
${ }^{1}$ Several papers investigate how socioeconomic status in adulthood affects portfolio decisions. For example, individuals with higher education, income and wealth hold a larger fraction of their financial wealth in stocks (McArdle, Smith and Willis, 2009). Cognitive skills and financial literacy are also found to influence portfolio decisions in older age, as these decisions may be cognitively demanding (Christelis, Jappelli and Padula, 2010; Jappelli and Padula, 2011, Van Rooij, Lusardi and Alessie, 2011). Finally, the household finance literature has examined the influence of health on portfolio choice (Rosen and Wu, 2004, Edwards, 2008; Yogo, 2016; Coile and Milligan, 2009) as well as that of age, with portfolios in retirement exhibiting reduced risk (Guiso, Haliassos and Jappelli, 2001; Ameriks and Zeldes, 2004).
} 
portfolio allocation by estimating the transition probabilities in and out of ownership for different financial assets. Our findings indicate that higher childhood SES and cognition make it less likely for households to sell their risky assets, and more likely to invest in them if they don't already own them.

There are several channels through which childhood experiences may affect financial decisions in adulthood. First, childhood conditions have direct implications for wealth later in life, which is in turn strongly associated with risky asset ownership. Oftentimes, an early life of deprivation has a negative effect on childhood health. Poor childhood health adversely affects cognition and wealth accumulation in adulthood, thus leading to the perpetuation of poverty (Palloni, 2006), the persistence of which across generations is well documented. ${ }^{2}$ More generally, there is ample evidence that the intergenerational correlation in incomes and income volatility is high (Solon, 1992; Shore 2011). The same is true for the intergenerational correlation in wealth, as documented by Charles and Hurst (2003), who also find that adults who have wealthy living parents are more likely to invest in risky assets like stocks.

Second, childhood conditions affect individuals’ stock of human capital. The benefits of positive early childhood experiences (as indicated by height) extend to the old age, as taller individuals enjoy better physical and mental health in later life (Case and Paxson, 2008). Furthermore, using height as a marker for lifelong experiences, Korniotis and Kumar (2010) find that taller individuals are more likely to participate in financial markets, and when they do so, they also hold riskier financial portfolios. Case, Fertig and Paxton (2005) in turn find that being born in a low SES family has a negative impact on childhood health, lowers investments in human capital and worsens health in early adulthood, all effects associated with lower adult earnings (see also Hanushek and Woessmann (2008) for a survey of the voluminous evidence

\footnotetext{
${ }^{2}$ Further evidence on the positive effect of health and socioeconomic status early in life on their counterparts in adulthood is given by Currie (2009), and Luo and Waite (2005).
} 
on the strong positive association between childhood cognition and adult earnings). Hence, health and cognitive problems in childhood are likely to put people at a disadvantage when they start their working lives. With diminished human capital, individuals will likely experience a lower lifetime income, with direct implications for portfolio choice.

Third, early life experiences may affect portfolio choice by shaping attitudes toward risk. For instance, a difficult childhood may lead to higher risk aversion in adulthood. Results from Hryshko, Luengo-Prado and Sorensen (2011) suggest that attitudes such as risk aversion are partly shaped by childhood SES. They find that besides age, gender, religion, and parents' risk aversion, a higher level of parental education makes children less risk averse in adulthood, which should lead to riskier portfolio allocations.

Fourth, childhood conditions may affect the rate of return of capital. For example, early cognitive skills are likely to have a direct impact on the level of financial sophistication later in life. Indeed, Lusardi, Mitchell and Curto (2010) find that the financial literacy of young adults in the US is strongly positively associated with their test scores in high school, as well as with their parents’ wealth. Furthermore, household finance literature has long recognized that financial sophistication affects saving and portfolio decisions (Lusardi and Mitchell, 2007; Behrman, Mitchell and Bravo, 2012; Lusardi, Michaud and Mitchell, 2017), with Van Rooij, Lusardi and Alessie (2011) showing financial literacy to correlate with higher chances to invest in the stock market and with greater wealth. Calvet, Campbell and Sodini (2009) construct an index of financial sophistication and show that poor financial sophistication explains a rich set of investment mistakes, which include under-diversification, inertia in risky shares of one’s portfolio, and the tendency to sell winning stocks and hold losing ones.

Fifth, childhood conditions may affect the type of uncertainties that an individual will have to face during adulthood. Having certain medical conditions early in life can lower life expectancy and lead to higher and more volatile health spending. Additionally, low cognitive 
abilities and childhood SES can reduce the chances of finding and keeping a job, thus leading to a less stable working life trajectory. In fact, Brandt and Hank (2011), using the same data as we do, find a strong positive association of childhood SES and health with income uncertainty in adulthood, as indicated by the prevalence of unemployment spells. As a result, higher exposure to risk in one dimension may lead people to reduce risks in other dimensions, for instance by increasing saving for precautionary reasons or by diminishing investments in risky assets like stocks. Empirical evidence for the former effect was provided by Caroll and Samwick (1997), who showed that people exposed to higher income insecurity systematically accumulate more wealth. Moreover, Guiso, Jappelli and Terlizzese (1996) and Heaton and Lucas (2000) find that when other independent risks are present, investors drop their exposure to rate-of-return risks, lowering the share of wealth in illiquid and risky assets (especially stocks).

In recent years, several studies have focused on the effects of education and cognition on stock market participation. In the U.S for instance, Cole, Paulson and Shastry (2014) find that education has large causal effects on financial participation and smaller effects on a households' finance management (as indicated by credit scores, bankruptcy, and foreclosure). The study also uses within-sibling variation in cognitive ability to highlight the importance of cognition for sound financial decision-making. In this context, however, using investment or retirement income as proxy for market participation is only partially informative about one's amount and type of investments. Conversely, Hryshko, Luengo-Prado and Sorensen (2012) use PSID data on direct risky assets ownership and find that education has a positive impact on the joint propensity to own stocks and mutual funds (outside of retirement accounts). Grinblatt, Koloharju and Linnainmai (2011) study the Finnish stock market participation as a function of IQ measured at age 19 or 20. They conclude that all IQ subcomponents (logical, verbal, and especially mathematical scores) have a significant impact on stock or mutual fund ownership 
later in life, with the economic effect of IQ being even larger than income's participation effect. Finally, Christelis, Jappelli and Padula (2010) find the propensity to invest in stocks to be strongly related with cognitive abilities in older age.

Our paper contributes to the literature on financial risk-taking in several dimensions. First, it examines the effect of cognition in childhood (at age 10) on financial risk-taking, net of the corresponding effect of education and adulthood cognition. Second, it highlights the influence of childhood SES and health on financial risk-taking, net of childhood cognition and net of any measures of economic resources in adulthood. Third, we provide this evidence for 11 different European countries, using harmonized survey data. Finally, as discussed below, we study the effects of our variables of interest on (i) the static choice of holding risky financial assets, and (ii) the decision to invest in or disinvest from them from one period to the next. Hence, our study sheds light on how our variables of interest affect the dynamics of financial risk taking.

Finally, we note that the link between childhood conditions and financial risk taking has also been briefly touched upon in Christelis, Dobrescu and Motta (2011, henceforth CDM). There are several fundamental differences between this study and CDM (e.g., different outcome variables, the examination of asset ownership transitions, etc.). These differences are discussed in detail in Appendix A.1.

The structure of the paper is as follows: Section 2 describes the data, while Section 3 discusses our estimation methodology. Baseline results are presented in Section 4, and several robustness checks are performed in Section 5. Section 6 concludes.

\section{Data}

We use data from the first two waves of Release 6.0.0 of SHARE, which took place in 2004-5 and 2006-7 in 11 European countries (Sweden, Denmark, Germany, the Netherlands, 
Belgium, France, Switzerland, Austria, Italy, Spain and Greece). ${ }^{3}$ SHARE surveys those aged 50+ and collects data on demographics, physical and mental health (including tests like grip strength), cognition, social activities, housing, employment, income, housing, assets and expectations. $^{4}$

In 2008-9 SHARE conducted its third wave (SHARELIFE), which was different from the first two ones because it mostly collected retrospective information on respondents' lives, from childhood to present. The questions covered, among other things, physical and mental health histories, early cognition, accommodation, working histories, and children and partner information. ${ }^{5}$ Importantly, the questionnaire in all three SHARE waves is completely harmonized across all participating countries.

Childhood SES is captured in SHARELIFE via two questions that refer to the house where respondents lived when they were 10 years old, namely to its (i) number of rooms (excluding kitchen, bathrooms, and hallways) ${ }^{6}$, and (ii) number of books in the house. There are five possible answers to (ii), expressed in the following ranges: 0-10, 11-25, 26-100, 101200, more than 200. As very few answers lie above the second range, we create a binary variable that is equal to one if the answer is above the first range, and zero otherwise.

To get information on childhood cognitive abilities we use two SHARELIFE questions that ask about relative school performance in mathematics and language at age 10. There are five possible answers to each of the two questions (i.e., performance was much better, better, about the same, worse, much worse than my peers). We create two binary variables that are equal to one if the respondents were much better or better, and zero otherwise.

\footnotetext{
${ }^{3}$ The second wave took place also in the Czech Republic, Poland, and Ireland, but given that we need to work with two-wave panel data we do not use the information from these countries.

${ }^{4}$ More details on waves 1 and 2 of SHARE can be found in Börsch-Supan et al. (2005), Börsch-Supan and Jürges (2005), Börsch-Supan et al. (2008).

${ }^{5}$ More details on SHARELIFE can be found in Börsch-Supan et al. (2011).

${ }^{6}$ Unfortunately, there is no information in SHARELIFE on the education of the respondents' parents.
} 
Finally, there are several questions in SHARELIFE that provide information on health during childhood. After experimenting with several of them, ${ }^{7}$ we finally chose for our baseline empirical specification to construct an indicator of health problems in childhood that equals one if respondents spent one or more months in the hospital or went to the hospital three or more times in one month during childhood.

Given that SHARELIFE is a retrospective survey, it would be natural to ponder how reliable are respondents' recollections about life events that took place many years back. The issue has been examined by Havari and Mazzona (2015, henceforth HM), who find that selfreported health and chronic diseases in childhood are not associated with cognitive and recall capacities in adulthood and are also congruent with measures of health in adulthood. Furthermore, measures of childhood SES, when aggregated across countries, correlate very strongly with historical country macroeconomic magnitudes like GDP per capita. Finally, HM also report that childhood cognition is, as expected, strongly associated with educational attainment. All in all, the HM findings suggest that SHARELIFE retrospective data are of reasonably good quality, similar to other surveys of this type. ${ }^{8}$

Following Christelis, Jappelli and Padula (2010), all our household-level specifications include childhood variables aggregated over the two partners in a couple (i.e., we take the maximum SES, cognition, and health problems variables over the two partners). When one of the partners' information is missing and non-imputed, we use the value of the responding partner. We test the robustness of our results to this treatment of missing values in Section 5 .

To assess the impact of childhood SES, cognition, and health on portfolio choice and risk taking in adulthood we chose to study the ownership of one's own house, as well as of four

\footnotetext{
${ }^{7}$ More details on variables denoting childhood health are given in Section 5.

${ }^{8}$ Smith (2009a, 2009b) documents this effect via two US surveys, namely the Health and Retirement Study and the Panel Study of Income Dynamics.
} 
types of financial assets, for which information can be found in both waves 1 and 2 (i.e., directly held stocks, mutual funds, IRAs, and bonds).

In the last few decades, large swings in housing prices have been observed in most developed countries. This volatility, combined with the very large share of housing in a typical households' wealth, as well as, among other factors, the timing of the house acquisition, the type of house chosen, and the location choice, clearly makes the decision to own a house a risky one. Furthermore, households can invest in stocks, which constitute the riskiest financial asset, through three of the four investment vehicles that SHARE collects information on (i.e., except via bonds), and the degree of riskiness should, for instance, be typically higher for directly held stocks than for IRAs. Both directly held stocks and mutual funds are considered, however, the more informationally demanding of the risky assets typically held by households. The ownership of these assets often requires acquiring considerable information on the issuing company characteristics and prospects, or on mutual funds investment strategies and performance. As a result, we would expect our early cognition variables (especially mathematical ability) to have their strongest effect on these two assets. They are also typically held by more prosperous segments of the population, so we would expect the influence of childhood SES to be especially strong for them. In contrast, bonds are the least risky of the financial assets considered, and thus we would expect the influence of childhood conditions on them to be relatively weak.

Besides home ownership and these four financial assets, we also examine the effect of childhood conditions on total risky asset ownership that covers stocks, mutual funds and IRAs. ${ }^{9}$ One advantage of this consolidated variable is that it reduces the misclassification error that could arise if respondents mistake one risky financial asset for another (e.g., if they hold mutual

\footnotetext{
${ }^{9}$ This is a common combination in the household finance literature (see Guiso, Haliassos and Jappelli, 2001).
} 
funds only through their IRAs and then report these holdings when asked about mutual funds). Its disadvantage is that it makes it difficult to isolate the differential effects of childhood conditions on various risky financial assets. As mentioned, one should expect such differential effects, given the varying risk profiles of stocks, mutual funds and IRAs.

Financial respondents in wave 2 were also asked about their risk preferences with respect to their investments. There were four possible answers related to whether respondents had the propensity to: (i) take substantial financial risks expecting to earn substantial returns; (ii) take above average financial risks expecting to earn above average returns; (iii) take average financial risks expecting to earn average returns; and (iv) not take any financial risks. As there were few respondents that chose the first three options, we created a binary variable equal to one if the household was willing to take any financial risk, and zero otherwise. Given that the question was asked only in wave 2, we could only perform a cross-sectional analysis when modeling the associated variable.

After merging the SHARELIFE data with those for waves 1 and 2 we ended up with a sample of about 18,150 households and 24,920 individuals. Information on the prevalence of the ownership of the four financial assets and on the propensity to take any financial risk can be found in Table 1. We note that the highest stockholding prevalence can be found in Sweden (46.6\%), and the lowest in Greece (3.9\%). These two countries represent the two extremes also in the case of mutual funds (51.9\% and $1.4 \%$, respectively). IRAs are also very prevalent in Sweden (44.5\%), while Italy and Greece display the lowest figures (about 1.7\%). Bond ownership is most widespread in Denmark (21.9\%) and least common in Greece (1\%).

With respect to our childhood-related variables of interest, we note that the countries with the highest prevalence of more than 10 books in the house are Sweden and Denmark (83.8\% and $82.6 \%$, respectively), while the lowest prevalence can be found in Italy (26.5\%). The largest average number of rooms in the house at age 10 can be found in Belgium (5.7), while 
the lowest in Greece (2.8). The two questions on early cognition show that Swedes and Danes are the most likely (at about 55\%) to perform above average in both mathematics and language, while the Greeks are the least likely (roughly 34\%). Notably, in most countries the majority of respondents report being below average or at most average compared to their peers, especially in math but also in language. Together with HM findings, this suggests that the childhood cognition measures are unlikely to suffer from recall bias due to overestimating one's ability. Finally, Austrians and Germans are the most likely to have spent 1+ months in the hospital (15.1\% and $15.6 \%$ respectively), while Greeks the least likely (roughly $1 \%) .{ }^{10}$

The associations between risky financial asset ownership and risk attitudes, as well as childhood conditions can be seen from Table 2. In it we show the prevalence of our variables of interest for both favorable and unfavorable outcomes in our measures of childhood SES, cognition and health. A quick glance reveals that households exhibiting higher childhood SES and cognition report significantly higher ownership of all financial assets, as well as a higher propensity to take financial risk. These positive associations are weaker, but still observed also with respect to housing. On the other hand, childhood health problems seem, if anything, to be correlated with risky ownership in the opposite direction than expected (i.e., positively). As we will see below, most of the tabulations recorded in Table 2 will be accurately mirrored in our estimation results.

\section{Methodology}

Our objective is to estimate, in a panel data setting, the effects of our childhood variables on the ownership of different financial assets, as well as on the transitions in and out of ownership. To do so, we use the semi-parametric discrete choice panel data model with

\footnotetext{
${ }^{10}$ The high prevalence of this measure of childhood health problems for Germany and Austria might be due to events related to World War II and its aftermath.
} 
autocorrelation developed in Christelis and Fonseca (2015). ${ }^{11}$ For the willingness to assume financial risks we use a probit model, as the estimation is performed on a cross-section.

Transitions of discrete choice outcomes are often estimated by starting with a sample of respondents for which the outcome takes a specific value, and then examining what happens in a subsequent wave: a new binary variable is defined to be equal to one if there is a change in the outcome in the next wave, and zero if there is no change. This approach is problematic because it entails starting with a potentially very selected sample that consists of those for which the outcome takes a particular value. For example, to study transitions out of stock ownership one would start with the sample of wave 1 stockowners. Selectivity can be a problem because the unobservables that affect the choice to be a stockholder (e.g., familiarity with the workings of the stock market) may also affect the transition out of stock ownership. In other words, only part of the sample is used, and the truncation is based on an endogenous decision, which can lead to inconsistent estimates.

A potential solution would be to model simultaneously the two ownership possibilities, each with two possible outcomes (no transition and transition), by using a multinomial logit with four total outcomes. Some of the outcomes, however, would be irrelevant (and thus impossible to choose) for some cases of ownership. For example, transitions from ownership to non-ownership would be irrelevant for non-owners. This inability to choose some of the options at any given point in time would be a violation of the multinomial logit assumptions. Alternatively, one could use a nested logit, but one of its assumptions would imply no correlation between unobservables of choices in different nests - hard to justify in our case. ${ }^{12}$

Our approach to estimating transitions starts from the specification of the household's decision problem - to own an asset or not. For this decision, we posit an equation for a latent

\footnotetext{
${ }^{11}$ The exposition in this section follows closely their arguments.

12 Note we cannot use panel discrete choice models with lagged dependent variables as we only have 2 waves.
} 
variable $y_{i, t}^{*}$ (for household $i$ ) given by

$$
y_{i, t}^{*}=\mathbf{X}_{i, t} \boldsymbol{\beta}+c_{k}+\varepsilon_{t}
$$

where $\mathbf{X}_{i, t}$ denotes a vector of control variables, $c_{k}$ a random effect, and $\varepsilon_{t}$ is a time varying noise term. As usual, there is an observed binary variable $y_{i, t}$ equal to one if the latent variable $y_{i, t}^{*}$ is greater than zero, and zero otherwise. We further assume that the random effect $c_{k}$ takes values from a distribution with $\mathrm{K}$ points (the first point $c_{1}$ is normalized to zero as in Michaud and Tatsiramos, 2011), and for each point $k(k=1, \ldots, \mathrm{K})$ there is an associated probability $p_{k}$. In other words, we estimate a non-parametric distribution for the random effect, as in Heckman and Singer (1984). The use of a non-parametric distribution for the random effects should make our results more robust than those obtained under the typical assumption that the random effect is normally distributed (Mroz, 1999). The combination of a nonlinear panel data model with a nonparametric random effect makes, however, the convergence of the likelihood function nontrivial. In each case we report results using the number of distribution points for which we obtain convergence of the likelihood function (see Appendix Tables A.1A-A.1B). Our results are not sensitive to the number of distribution points, conditional on obtaining convergence of the likelihood function.

Finally, the distribution of the noise $\varepsilon_{t}$ is crucial in our context. More specifically, we assume that it is autocorrelated, with correlation coefficient $\rho$,

$$
\varepsilon_{t}=\rho \varepsilon_{t-1}+w_{t}
$$

and $w \sim N\left(0, \sigma^{2}\right)$. We allow for this autocorrelation of the noise term to account for unobservable factors affecting portfolio choice that are not independent over time. For example, some investors might be familiar with the stock market because they are acquainted with people professionally involved in it and who can give them with stock tips. Such a source 
of information can be reasonably assumed to be present in more than one time period.

Equation (2) and the distributional assumption on $w$ imply an $\varepsilon_{t}$ is normally distributed with mean zero and variance $\sigma^{2} /\left(1-\rho^{2}\right)$. As usual in a probit model, we need a normalization in the distribution of $\varepsilon_{t}$. Consequently, we divide the linear index of the latent variable by the standard deviation of $\varepsilon_{t}$, and set $\sigma=1$. This in turn means that the linear index $\boldsymbol{X}_{i, t} \boldsymbol{\beta}$ and the random effect $c_{k}$ added to it will be both multiplied by $\sqrt{1-\rho^{2}}$ in the likelihood function.

All the above imply that the probability of observing any combination of the two possible choices (one decision in each of the two periods in our sample) can be written, for a given point $\mathrm{c}_{k}$ of the distribution of the random effects, as follows:

$$
h\left(\mathbf{y}_{i} \mid \mathbf{X}_{i}, c_{k} ; \boldsymbol{\beta}, \rho\right)=\Phi_{2}\left(l_{i, t}\left(\mathbf{X}_{i, t} \boldsymbol{\beta}+c_{k}\right) \sqrt{1-\rho^{2}}, l_{i, t+1}\left(\mathbf{X}_{i, t+1} \boldsymbol{\beta}+c_{k}\right) \sqrt{1-\rho^{2}}, l_{i, t} l_{i, t+1} \rho\right)
$$

where $\mathbf{y}_{i}=\left(y_{i, t}, y_{i, t+1}\right), \mathbf{X}_{i}=\left(\mathbf{X}_{i, t}, \mathbf{X}_{i, t+1}\right), l_{i, t}=2 y_{i, t}-1, l_{i, t+1}=2 y_{i, t+1}-1$, and $\Phi_{2}$ denotes the bivariate cumulative standard normal distribution. Hence, the log likelihood of our sample can be written as

$$
\log L(\boldsymbol{\beta}, \rho, \mathbf{c}, \mathbf{p})=\sum_{i=1}^{N}\left(\log \sum_{k=1}^{K} p_{k}\left[h\left(\mathbf{y}_{i} \mid \mathbf{X}_{i}, c_{k} ; \boldsymbol{\beta}, \rho\right)\right]\right)
$$

where $\mathrm{c}=\left(\mathrm{c}_{2}, \ldots, \mathrm{c}_{\mathrm{K}}\right)$ and $\mathrm{p}=\left(\mathrm{p}_{2}, \ldots, \mathrm{p}_{\mathrm{K}}\right)^{13}$

The study of transitions in asset ownership between the two periods comes naturally out of this setup if we consider that a transition probability is just a probability of an outcome at $t+1$ conditional on an outcome at $t$, thus equal to the joint probability of the two outcomes divided by the marginal probability of the conditioning outcome at time $t$. The existence of $\rho$ implies that the joint probability is not equal to the product of the marginal probabilities of the two outcomes; hence, the conditional probability will not collapse to the marginal probability

\footnotetext{
${ }^{13}$ More details on the maximization of the likelihood with respect to $\rho$ and $\boldsymbol{p}$ are given in Appendix A.2.
} 
of the outcome at $t+1$. Starting from (3), we can calculate the probability of transitioning from ownership of an asset at time $t$ to non-ownership at time $t+1$ as follows:

$$
\operatorname{prob}\left(y_{t+1}=0 \mid y_{t}=1\right)=\sum_{k=1}^{K} p_{k} \frac{\Phi_{2}\left(\left(\mathbf{X}_{i, t} \boldsymbol{\beta}+c_{k}\right) \sqrt{1-\rho^{2}},-\left(\mathbf{X}_{i, t+1} \boldsymbol{\beta}+c_{k}\right) \sqrt{1-\rho^{2}},-\rho\right)}{\Phi\left(\left(\mathbf{X}_{i, t} \boldsymbol{\beta}+c_{k}\right) \sqrt{1-\rho^{2}}\right)}
$$

that is, by dividing the joint probability of ownership at $t$ and non-ownership at $t+1$ by the marginal probability of ownership at t and integrating the resulting conditional probability over the distribution of the random effect.

Equation (5) makes it clear that we can form the joint probabilities needed to calculate transition probabilities only because of the presence of $\rho$. If $\rho$ were zero, the conditional probability in (5) would collapse to the marginal probability of the outcome at $t+1$ for any value of the random effect $c_{k}$.

The probability of a transition from non-ownership in $t$ to ownership in $t+1$ is calculated in analogous fashion as follows:

$$
\operatorname{prob}\left(y_{t+1}=1 \mid y_{t}=0\right)=\sum_{k=1}^{K} p_{k} \frac{\Phi_{2}\left(-\left(\mathbf{X}_{i, t} \boldsymbol{\beta}+c_{k}\right) \sqrt{1-\rho^{2}},\left(\mathbf{X}_{i, t+1} \boldsymbol{\beta}+c_{k}\right) \sqrt{1-\rho^{2}},-\rho\right)}{\Phi\left(-\left(\mathbf{X}_{i, t} \boldsymbol{\beta}+c_{k}\right) \sqrt{1-\rho^{2}}\right)}
$$

Note that conditional probabilities like the ones in (5) and (6) do not require outcomes defined as transitions; instead they are naturally derived from combinations of the static outcomes by taking advantage of the autocorrelation in the noise. In addition, the calculation of these transition probabilities does not require the presence of a lagged dependent variable, which would not be possible in our case because we have a two-period panel. ${ }^{14}$

We now give an illustration of how the autocorrelation in $\varepsilon_{t}$ affects stockholding by

\footnotetext{
${ }^{14}$ Obviously, the probabilities of making the same choice in both periods are equal to one minus their respective transition probabilities between different outcomes. In other words, $\operatorname{prob}\left(\mathrm{y}_{\mathrm{t}+1}=1 \mid \mathrm{y}_{\mathrm{t}}=1\right)=1-\operatorname{prob}\left(\mathrm{y}_{\mathrm{t}+1}=\left.0\right|_{\mathrm{t}}=1\right)$ and $\operatorname{prob}\left(\mathrm{y}_{\mathrm{t}+1}=0 \mid \mathrm{y}_{\mathrm{t}}=0\right)=1-\operatorname{prob}\left(\mathrm{y}_{\mathrm{t}+1}=1 \mid \mathrm{y}_{\mathrm{t}}=0\right)$. As a result, the marginal effect of any variable in $\boldsymbol{X}$ on the probability of making the same choice in both periods is equal to minus the marginal effect on the associated transition probability of making the opposite choice.
} 
operating on the level of the latent variable $y_{t}^{*}$ in (1). Take a case of positive autocorrelation and suppose that there is a positive shock to $\varepsilon_{t}$. An example of such a shock would be getting to know a person knowledgeable about individual stocks, who gives the household useful tips that induce it to invest in such stocks. This acquaintance would be unobservable to the econometrician, and thus would be part of the error term $\varepsilon_{t}$. A larger $\varepsilon_{t}$ also implies a larger $y_{t}^{*}$ that makes it more likely for $y_{t}^{*}$ to get over the threshold that makes stockholding positive. Hence, the household is more likely to invest in stocks in period $t$. A positive autocorrelation implies that if $\varepsilon_{t}$ is large, then $\varepsilon_{t+1}$ and thus $y_{t+1}^{*}$ are also likely to be large. This makes stockholding in period $t+1$ more likely. Hence autocorrelation makes choices dependent across time, while still affecting the levels of the latent index in each period.

It follows that our model allows us to calculate the marginal effects of our childhood variables on the probabilities of: (i) ownership (unconditional); (ii) switching from ownership to non-ownership; and (iii) switching from non-ownership to ownership. In other words, one can define a marginal effect of any variable in $\boldsymbol{X}$ on a transition probability, just as one does for the usual static ownership probability. It is also true that if a variable in $\boldsymbol{X}$ has a positive effect on the static ownership probability, then it will also make the joint probability of positive ownership in both periods larger (and the joint probability of owning in one period and not owning in the other smaller). However, as the conditional probability is equal to the joint over the two periods divided by the marginal in the first period, the denominator of the conditional probability will also become larger in this case. Consequently, the overall effect of a change of a variable in $\boldsymbol{X}$ on the conditional probability of ownership in the second period given ownership in the first will differ from the effect on the static ownership probability. This example illustrates why it is useful to separately calculate the marginal effects on the static and transition probabilities of ownership.

At first glance, it might appear a bit odd that time-invariant factors like early life 
conditions might affect how behavior evolves from one period to the next. The channels through which the influence of childhood circumstances materializes are, however, the same ones as for the static asset ownership choice. For example, the higher stock of human capital in older age that is associated with high childhood SES and cognition can bring about the circumstances that trigger financial market participation (Korniotis and Kumar, 2010), Obviously, this influence of childhood conditions is present in all periods, thus making the 11 transition more likely. In addition, a higher willingness to bear financial risk, partly induced by favourable childhood circumstances, should make divesting from risky assets less likely, thus leading to a more stable and long-run-oriented investment strategy. Finally, higher childhood cognition can increase the level of financial sophistication in adulthood, which in turn can lead to less financial inertia and allocation mistakes, including under-diversification or inappropriate changes in portfolio composition.

When calculating the marginal effects on transition probabilities, we calculate the conditional probability for a given value of the forcing variable in both periods, then calculate the same probability for a second value of the forcing variable (again constant across time) and then take the difference of the two conditional probabilities. For the dummy variables denoting being above average at math and language, for having more than ten books in the house, and for spending one or more months in the hospital, the marginal effects denote the change in the relevant probability when the dummy variable changes from zero to one. For the number of rooms in the house the marginal effect reflects the change in the probability when the rooms increase by one. We estimate our marginal effects and their standard errors by simulation; the procedure that we follow is described in detail in Appendix A.2.

One final note relates to the calculation of transition probabilities and their associated marginal effects being a partly counterfactual exercise, as is also the case with the usual unconditional (i.e., marginal) probabilities. When we consider the probability of, say, direct 
stockholding and how it is affected by a change in the value of a variable of interest, we calculate this probability also for households that are not observed to own stocks directly in our sample. Similarly, we calculate the probability of a particular transition in the ownership of an asset also for sample units that do not exhibit this ownership pattern over time.

\section{Empirical Results}

This section presents the marginal effects related to the influence of our five variables of interest denoting childhood SES, cognition, and health on the ownership probabilities of: (i) the four assets (stocks, mutual funds, IRAs, bonds); (ii) the aggregated measure of risky financial assets; (iii) the willingness to take at least some financial risk; and on the transitions in and out of ownership of the aforementioned assets. In addition to our variables denoting childhood conditions, all our specification include several other variables that have been found to be key determinants of risky asset ownership in the household finance literature. These include age, marital status, number of children, self-reported bad health status, the number of chronic health conditions, education, two cognition indicators (one derived from a numeracy test, ${ }^{15}$ and one denoting self-reported good reading skills), retirement status, having received an inheritance, real and financial wealth, and household income. ${ }^{16,17}$ The variables denoting education, numeracy and reading skills, health and financial resources are particularly important because they represent SES and cognition in adulthood. As a result, whatever effects we find from our childhood conditions variables will be net of the corresponding variables in adulthood. For the two individual-level outcomes (ownership of IRAs and willingness to take financial risk) we also add a gender dummy. To account for multi-country variability, given

\footnotetext{
${ }^{15}$ See Christelis, Jappelli and Padula (2010).

${ }^{16}$ As for childhood conditions, in household-level specifications we aggregate variables over the couple.

${ }^{17}$ Financial wealth is net of the value of the financial asset whose ownership is examined, while in the case of housing real wealth excludes it. Household income is net of capital income.
} 
our sample, we also include country dummies. These could capture, among other things, country differences in institutions or tax laws. Finally, we also cluster our errors at the country level to capture the effect of any (possibly time-varying) unobservable factors that affect sample units in a given country.

As is well-known, regression coefficients in non-linear discrete choice models do not allow us to calculate economically relevant magnitudes, and thus we show them in Appendix Tables A1.A and A1.B. One important regression result, however, is that the autocorrelation coefficient $\rho$ is very large in absolute value and strongly significant for all the assets examined except directly held stocks and IRAs, as well as for total risky financial asset ownership. These results justify our approach that allows for autocorrelation in the error terms of our panel model and uses $\rho$ to calculate probabilities of ownership transitions and the associated marginal effects thereof.

Turning our attention to the marginal effects, Table 3 shows the effects of our variables of interest on the unconditional (static) ownership probabilities and on the probability to assume financial risk. For directly held stocks, we find that (i) having more than 10 books in the house increases of the ownership probability by 3.2 percentage points (pp), while (ii) being above average at math increases the probability by 3.3 percentage point (pp). As about $13 \%$ of households in our sample own stocks directly, these results are economically significant. They are also unsurprisingly smaller than previously found in CDM - as our childhood estimates are now net of current health status and cognitive skills. Turning to mutual funds, the SES variable that matters is having more than ten books in the house (2.2 pp), while being above average at math has once more a strong effect (1.3 pp). Better language abilities also have a positive but weaker effect (0.9 pp). The number of books is also strongly and positively related with IRAs (1.5 pp). Once more, our results for both mutual funds and IRAs are economically important, as ownership prevalence in our sample is about $13 \%$ for the former and $12 \%$ for the latter. 
These results confirm our intuition that the influence of childhood mathematics aptitude is particularly relevant for informationally demanding assets like directly held stocks and mutual funds. ${ }^{18}$ Furthermore, we also note the strong effect of childhood SES for these two assets, which is again not a surprise, given that they are mostly held by the wealthiest part of our sample (the same is true for IRAs).

When we examine the ownership of the aggregated risky asset ownership, we find that having some books in the house increased the probability of ownership by 3.9 pp, while being above average at math increased it by $1.8 \mathrm{pp}$. Given that about $28 \%$ of households in our sample own risky financial assets in any form, the above effects are not only statistically significant but also economically relevant. Importantly, these results suggest that our findings pertaining to individual risky financial assets are unlikely to be affected by any misclassification of risky asset ownership by the respondents.

As for homeownership, we again find that SES - as measured by the number of rooms in the house at 10 years old - makes it more likely to own a house in older age (the marginal effect is equal to $1.1 \mathrm{pp}$ ), while being better than average at math also increases the ownership probability by $3.9 \mathrm{pp}$. Interestingly, the owned house is the only asset that appears related to childhood health. Indeed, spending some time in the hospital reduces the probability of ownership by 3.3 pp. $^{19}$ Given that the prevalence of homeownership is about $71 \%$ in our sample, all these results are economically significant.

\footnotetext{
${ }^{18}$ Compared to CDM (2011), mathematical skills estimates are smaller and language effects - previously weaker - are now irrelevant, both differences likely due to current estimates being net of current cognition and economic resources.

${ }^{19}$ In CDM, childhood health variables have generally larger estimated effects than the ones in this study. One reason for this difference is that CDM use as measures of childhood health two different variables, namely (i) self-reported childhood health, found to mater only for one's chances of ever owning stocks in Sweden, and (ii) availability of a usual source of care during childhood.
} 
Bonds are the only financial assets for which we find no association with any of our variables of interest. This finding is not surprising because bonds are the least risky assets that we examine. As a result, we would expect the effects of early life conditions to be weak for this particular asset. This is in line with the finding in Bucciol and Zarri (2015) that show for this particular asset the only thing that seems to have an effect on its ownership is arguably the most extreme traumatic situation one could experience (i.e., the loss of one's child). In other words, this result reinforces our intuition that a crucial channel through which childhood conditions affect adulthood is the willingness to undertake risk.

Finally, the willingness to take some financial risk (found in about 22\% of households) is strongly affected by having more than ten books (4.1 pp), and a larger number of rooms (0.5 pp) in the house at age ten. This is in line with the opposite finding that severe episodes of hunger earlier in life are causally related to less willingness to take financial risks, with these estimates offsetting about a third of the positive effect of our first SES indicator (Christelis and Dobrescu, 2018). Being better than average at math also increase the propensity to undertake financial risk by 2 pp.

Looking briefly at variables other than those of interest (shown in Appendix Tables A1.A-A.1B), we note that our results confirm to a very large extent both previous findings in the household finance literature and our own intuition: We find a strong positive influence of higher education, current cognition, economic resources, and receipt of an inheritance on all financial assets considered, while the associations with being in bad health are in general negative. The same patterns are also present in our cross-sectional probit results for the willingness to take financial risk ${ }^{20}$ and confirm previous literature findings from the literature (e.g., Halek and Eisenhauer, 2001).

\footnotetext{
${ }^{20}$ The baseline specification for the willingness to take financial risk omits economic resources variables due to possible reverse causality between them and the attitude towards risk. Including these variables leaves our results unchanged.
} 
This analysis of the probability of asset ownership transitions enriches our results by allowing the study of how investors update their choices over time. Consider first the results on the probability of divesting an asset (Table 4). We find that higher childhood SES and cognition make it less likely that households will want to sell their assets. We note in particular the strong negative effects of being above average at math on divesting from stocks and mutual funds (-3.4 pp and -1.5 pp, respectively), as well as the negative effects of childhood SES (as indicated by having more than 10 books in the house) on divesting from directly held stocks, mutual funds and IRAs (-3.3, -2.7 and $-1.6 \mathrm{pp}$, respectively). These effects are mirrored in the aggregated risky asset ownership: having more than 10 books in the house and being above average at math make divesting less likely by 3.4 pp and 1.6 pp, respectively. Finally, one more room in the childhood home reduces the probability of transitioning out of homeownership by 0.3pp, being better than average at math by $1.2 \mathrm{pp}$, while having spent time at the hospital increases it by 1 pp.

Next we examine the opposite transition probability - of investing in the asset in period $t+1$ after not owning it in period $t$ (Table 5). Note that childhood cognition and SES are positively associated with investing in risky assets, with similar effects (in absolute value) than those found for the divesting probability. Once more, above average mathematical skills are positively associated with investing in stocks (3.2 pp) and in mutual funds (0.9 pp). In addition, having more than 10 books in the house has a positive effect on investing in directly held stocks (3.1 pp) mutual funds (1.5 pp), and on opening an IRA (1.6 pp). One more room in the childhood home increases the probability of transitioning into homeownership by 0.5 pp, being better than average at math by $1.6 \mathrm{pp}$, while having spent time at the hospital decreases it by 1.3 pp. Finally, the results for aggregated risky financial asset ownership are also similar: having more than 10 books in the house and being above average at math make investing more likely by 3.1 pp and 1.4 pp, respectively. 
Our findings are somewhat striking. Typically, individuals are exposed to increasing uncertainty as they age, mostly due to adverse health shocks becoming more severe and frequent, which in turn leads to significant health costs. Increased exposure to risk in one dimension should lead individuals to reduce risks in other dimensions, for instance by reducing investments in risky assets (Caroll and Samwick, 1997; Guiso, Jappelli and Terlizzese, 1996; Heaton and Lucas, 2000). In addition, the shorter expected lifetime that comes about with aging, means that there is less time available to recover from an adverse asset price shock. Therefore, it is not surprising that the risky content of household portfolios declines with age (Ameriks and Zeldes, 2004). Our results show that higher childhood SES and cognition mitigate this pattern, both by diminishing the propensity to drop risky investments with age and by increasing, ceteris paribus, the willingness to undertake them.

To summarize, we find that both childhood SES and cognition have economically relevant positive associations with home ownership and three of the four financial assets that we examine, as well as with our aggregated measure of risky financial asset ownership. It is important to emphasize that these associations are net of the strong effects of current SES (i.e., education and economic resources), and current cognition. We must also remember that early SES and cognition should have an effect on their current counterparts; therefore, it is very likely that our estimated marginal effects are conservative estimates of the overall effect of childhood cognition and SES on asset ownership and risk taking in older age.

\section{Robustness checks}

To check the robustness of our results, we experiment with various specifications of our estimating equations. Due to space constraints we cannot show all the results from these checks; they are available from the authors upon request. 
We first run conventional random effects probits without autocorrelation to see whether (i) our non-parametric specification of heterogeneity, and (ii) our modeling of autocorrelation significantly affect our estimates. We find the random effect probits results to be very similar to our baseline ones. We thus conclude that neither (i) nor (ii) are likely to introduce biases in our estimation. Due to its semi-parametric nature, however, our model should be more robust to the misspecification of the random effect, while the inclusion of autocorrelation allows the estimation of transition probabilities.

Missing values in SHARE have been multiply imputed, with five imputed values generated for each missing one (Christelis, 2011). In our baseline results we use one of the five implicate datasets (chosen randomly), and thus as a robustness check we redid the analysis using all five of them to account for the increased variability due to imputation (Rubin, 1987). We found no difference in our results when using all five implicate datasets.

As there is attrition in the panel between waves 1 and 2, we re-estimated our empirical model using inverse probability weights equal to the inverse of the estimated probability of staying in the sample in wave 2. Following Wooldridge (2002), we obtained this estimated probability through a probit in which non-attrition was correlated to a set of covariates observed in the wave 1 . We found that the results obtained were virtually identical to those from our baseline specification.

We also examine the effect of childhood conditions on an additional financial asset, namely whole life insurance that is owned by about $19 \%$ of households. Whole life insurance policies have a saving component that accumulates over time, and thus can be potentially invested in risky financial assets. We find that whole life insurance ownership is positively, yet weakly associated with having more than 10 books in the house (3.3 pp), while early cognition has a strong effect via above average language skills (1.7 pp). 


\section{Conclusions}

This paper studies the influence of childhood SES, cognition, and health on owning financial assets and risk preferences in older age. We find that SES and cognition early in life have a lasting and economically significant effect on household investment choices and risk preferences, even after controlling for current SES and cognition. While childhood SES has a strong association with owning a house and all financial assets examined, the influence of cognition (via above average math ability) is strongest for the most informationally demanding assets (i.e., directly held stocks, mutual funds). Interestingly, childhood health effects were not statistically different from zero, with the exception of the owned home. All these results are robust to a variety of alternative specifications and estimation procedures.

Methodologically, our paper contributes to the household finance literature by showing how to take advantage of the autocorrelation of the noise term in panel data models to study transitions. This approach also allows us to use the whole sample for our estimation, and hence avoid the selectivity problems that affect estimation in truncated samples. While our results are economically relevant and new, they cannot be interpreted causally despite the longitudinal design of the study, due to the possible existence of measurement error and omitted variables that could be correlated with our regressors of interest. ${ }^{21}$ On the other hand, both (i) the robustness of our results to the inclusion of a large set of background SES and cognition indicators, and (ii) the zero effects we find for bonds, make a causal interpretation less objectionable. Moreover, our results are in line with those from studies finding a causal link

\footnotetext{
${ }^{21}$ If childhood variables suffer from measurement error, they will be a noisy proxy for actual early life conditions and bias our results. Moreover, childhood measures are self-reported and factors such as the respondents' SES and demographic characteristics may impact their recall about childhood events. We control for many such factors but some (e.g., parental education) are not available in SHARE. Hence, we might face an omitted variables problem.
} 
between a harsh childhood and adult labor or education outcomes (e.g., Ichino and WinterEbmer, 2004; Akbulut-Yuksel, 2014).

Policy-wise, our findings point out to early childhood conditions as one potential answer to the puzzle of why so many households do not invest at all in risky financial assets, a behavior that is inconsistent with the predictions of standard models of portfolio choice. It appears that adverse childhood conditions leave permanent effects on individuals' cognitive capacities and risk preferences, making them reluctant to undertake risky investments. It is thus likely that policy interventions early in childhood have, among other things, the potential to increase people’ ability to boost their wealth in adulthood through judicious choice of investments. Judging from our results, such interventions should include measures to alleviate conditions such as poverty, and/or to improve school performance. Doing better at school should in turn lead to higher financial literacy in adulthood, making investment in financial assets and housing less daunting.

Acknowledgements: We are grateful to Denise Doiron, Randy Ellis, Denzil Fiebig, Dimitris Georgarakos, Kent Smetters and to seminar participants at many institutions, for comments and suggestions. The SHARE data collection has been primarily funded by the European Commission's 5th framework programme (project QLK6-CT-2001-00360 in the thematic programme Quality of Life). Further support by the European Commission's 6th framework programme (projects SHARE-I3, RII-CT-2006-062193, as an Integrated Infrastructure Initiative COMPARE, CIT5-CT-2005-028857 as a project in Priority 7, Citizens and Governance in a Knowledge Based Society, and SHARE-LIFE CIT4-CT-2006-028812) and through the 7th framework programme (SHARE-PREP No. 211909, SHARE-LEAP No. 227822) is gratefully acknowledged. Co-funding for add-ons such as the training programme for SHARE interviewers came from the U.S. National Institute on Aging (U01 AG09740-13S2, P01 AG005842, P01 AG08291, P30 AG12815, R21 AG025169, Y1-AG-4553-01, IAG BSR06-11 and OGHA 04-064). All errors remain our own. 
Funding: This research did not receive any specific grant from funding agencies in the public, commercial, or not-for-profit sectors.

\section{References}

Akbulut-Yuksel, M. (2014) 'Children of war the long-run effects of large-scale physical destruction and warfare on children.’ Journal of Human Resources, 49(3), 634-662.

Ameriks, J., Zeldes, S.P. (2004) 'How do Portfolio Shares Vary with Wealth?' Mimeo, Columbia University.

Behrman, J.R., Mitchell, O.S., Soo, C., Bravo D. (2012) 'Financial Literacy, Schooling, and Wealth Accumulation.' American Economic Review, 102(3), 300-304.

Börsch-Supan A., Brugiavini A., Jürges H., Mackenbach J., Siegriest J., Weber G., eds. (2005) Health, Aging and Retirement in Europe: first results from the Survey of Health, Aging and Retirement in Europe. Mannheim Research Institute for the Economics of Aging: Mannheim.

Börsch-Supan A., Jürges H., eds. (2005) Health, Aging and Retirement in Europe Methodology. Mannheim Research Institute for the Economics of Aging: Mannheim.

Börsch-Supan, A., Brugiavini A., Jürges H., Kapteyn A., Mackenbach J., Siegriest J., Weber G., eds. (2008) First Results from the Survey on Health, Aging and Retirement in Europe (2004-2007): Starting the Longitudinal Dimension. Mannheim: Mannheim Research Institute for the Economics of Aging.

Börsch-Supan, A., Brandt M., Hank K., Schröder M., eds. (2011). The Individual and the Welfare State. Life Histories in Europe. Heidelberg: Springer.

Brandt, M., Hank, K (2011) 'Early and Later Life Experiences of Unemployment under Different Welfare Regimes.' In The Individual and the Welfare State: Life Histories in Europe, A. Börsch-Supan, M. Brandt, K. Hank and M. Schröder (eds.). Heidelberg: Springer, 2011. 
Bucciol, A., Zarri, L. (2015) 'The shadow of the past: Financial risk taking and negative life events.’ Journal of Economic Psychology, 48, 1-16.

van Buuren, S., Brand, J.P.L., Groothuis-Oudshoorn, C.G.M., Rubin, D.B. (2006) 'Fully Conditional Specification in Multivariate Imputation.' Journal of Statistical Computation and Simulation, 76, 1049-1064.

Calvet, L.E., Campbell, J.Y., Sodini, P. (2009) 'Measuring the Financial Sophistication of Households.' American Economic Review, 99(2), 393-398.

Carroll, C.D., Samwick, A.A. (1997) 'The Nature of Precautionary Wealth.' Journal of Monetary Economics, 40(1), 41-71

Case, A., Paxson, C. (2008) ‘Height, Health, and Cognitive Function at Older Ages.' American Economic Review, (2), 463-467.

Case, A., Fertig, A., Paxson, C. (2005) 'The Lasting Impact of Childhood Health and Circumstance.' Journal of Health Economics, 24(2), 365-389.

Charles, K.K., Hurst E. (2003) 'The Correlation of Wealth across Generations.' Journal of Political Economy, 111(6), 1155-82.

Christelis, D., Jappelli T., Padula M. (2010) 'Cognitive Abilities and Portfolio Choice.' European Economic Review, 54(1), 18-38.

Christelis, D. (2011) 'Imputation of missing data in Waves 1 and 2 of SHARE.' SHARE Working Paper 01-2011.

Christelis, D., Dobrescu L.I., Motta A. (2011) 'The Impact of Childhood Health and Cognition on Portfolio Choice.' In The Individual and the Welfare State: Life Histories in Europe, A. Börsch-Supan, M. Brandt, K. Hank and M. Schröder (eds.). Heidelberg: Springer, 2011.

Christelis, D. and Fonseca, R. (2015). 'Transition Probabilities in Panel Probit Models with Autocorrelation and Selectivity.’ Mimeo, CSEF, University of Naples Federico II. 
Christelis, D., Dobrescu, L.I. (2018) 'Traumatic Life Events and Financial Risk-Taking: The Enduring Impact of Hunger.' SSRN Working Paper https://ssrn.com/abstract=3308244. Coile, C.C., Milligan, K.S. (2009) 'How Household Portfolios Evolve After Retirement: The Effect of Aging and Health Shocks.' Review of Income and Wealth, 55(2), 226-248.

Cole, S.A., Paulson, A.L., Shastry, G.K. (2014) 'Smart Money? The Effect of Education on Financial Behavior.’ Review of Financial Studies, 27(7), 2022-2051.

Currie J. (2009) 'Healthy, Wealthy, and Wise: Socioeconomic Status, Poor Health in Childhood, and Human Capital Development.' Journal of Economic Literature, 47(1), 87-122.

Edwards, R.D. (2008) 'Health Risk and Portfolio Choice.' Journal of Business and Economic Statistics, 26 (4), 472-485.

Grinblatt, M., Koloharju, M., Linnainmai, J. (2011) 'IQ and Stock Market Participation.' Journal of Finance, 66(6), 2121-64.

Guiso, L., Jappelli, T., Terlizzese, D. (1996) 'Income Risk, Borrowing Constraints, and Portfolio Choice.’ American Economic Review, 86(1), 158-72.

Guiso, L., Haliassos, M., Jappelli, T. (2001) Household Portfolios. Cambridge: MIT Press.

Halek, M., Eisenhauer, J.G. (2001) 'Demography of risk aversion.' Journal of Risk and Insurance, 68, 1-24.

Haliassos, M., Bertaut, C. (1995) 'Why Do So Few Hold Stocks?' Economic Journal, 105, 1110-1129.

Hanushek, E., Woessmann, L. (2008) 'The Role of Cognitive Skills in Economic Development.' Journal of Economic Literature, 46(3), 607-668.

Havari, E., Mazzonna, F. (2015). 'Can we trust older people's statements on their childhood circumstances? Evidence from SHARELIFE.' European Journal of Population, 31(3), 233-257. 
Heaton, J., Lucas, D. (2000) 'Portfolio Choice and Asset Prices: the Importance of Entrepreneurial Risk.’ Journal of Finance, 55, 1163-98.

Heckman, J., Singer, B. (1984) 'A Method for Minimizing the Impact of Distributional Assumptions in Econometric Models for Duration Data.’ Econometrica, 52(2), 271-320. Hryshko, D., Luengo-Prado, M.J., Sorensen, B.E. (2011) 'Childhood Determinants of Risk Aversion: The Long Shadow of Compulsory Education.' Quantitative Economics, 2(1), $37-72$.

Hryshko, D., Luengo-Prado, M.J., Sorensen, B.E. (2012) 'The Effect of Education on Equity Holdings.' B.E. Journal of Economic Analysis and Policy, 12(1).

Ichino, A., \& Winter-Ebmer, R. (2004) 'The long-run educational cost of World War II.' Journal of Labor Economics, 22(1), 57-87.

Kennickell, A.B. (1991) 'Imputation of the 1989 Survey of Consumer Finances: Stochastic Relaxation and Multiple Imputation.' Proceedings of the Section on Survey Research Methods, 1991 Annual Meeting of the American Statistical Association, Atlanta, GA.

Korniotis, G., Kumar, A. (2010) 'Tall versus Short: Height, Lifelong Experiences, and Portfolio Choice.’ Working Paper Federal Reserve Board \& University of Texas Austin. Luo, Y., Waite, L.J. (2005) 'The Impact of Childhood and Adult SES on Physical, Mental, and Cognitive Well-Being in Later Life.' The Journal of Gerontology Series B: Psychological Sciences and Social Sciences, 60(2), 93-101.

Lusardi, A., Mitchell, O.S. (2007) ‘Baby Boomer Retirement Security: The Roles of Planning, Financial Literacy, and Housing Wealth.’ Journal of Monetary Economics, 54(1), 205224.

Lusardi, A., Michaud, P-C., Mitchell, O. S. (2017) ‘Optimal Financial Knowledge and Wealth Inequality.' Journal of Political Economy, 125, 431-477. 
Lusardi, A., Mitchell, O. S., Curto, V. (2010) 'Financial Literacy among the Young.’ Journal of Consumer Affairs, 44, 358-380.

McArdle, J., Smith, J.P., Willis, R. (2009) 'Cognition and Economic Outcomes in the Health and Retirement Survey.' New Directions in the Economics of Aging, University of Chicago Press.

Michaud, P.C., Tatsiramos, K. (2011) 'Fertility and Female Employment Dynamics in Europe: The Effect of Using Alternative Econometric Modeling Assumptions.' Journal of Applied Econometrics, 26 (4), 641-668.

Mroz, T.A. (1999) 'Discrete Factor Approximations in Simultaneous Equation Models: Estimating the Impact of a Dummy Endogenous Variable on a Continuous Outcome.' Journal of Econometrics, 92, 233-274.

Palloni, A. (2006) 'Reproducing Inequalities: Luck, Wallets, and the Enduring Effects of Childhood Health.’ Demography, 43(4), 587-615.

Rosen H., Wu, S. (2004) ‘Portfolio Choice and Health Status.’ Journal of Financial Economics, 72, $457-84$.

Rubin, D.B. (1987) Multiple Imputation for Nonresponse in Surveys. New York, NY: John Wiley \& Sons.

Shore, S.H. (2011) 'The Intergenerational Transmission of Income Volatility: Is Riskiness Inherited?’ Journal of Business and Economic Statistics, 29(3), 372-381.

Smith, J. P. (2009a) 'The impact of childhood health on adult labor market outcomes.' The Review of Economics and Statistics, 91(3): 478-489.

Smith, J. P. (2009b) 'Re-constructing Childhood Health Histories.’ Demography, 46(2): 387403.

Solon, G. (1992) 'Intergenerational Income Mobility in the United States.’ American Economic Review, 82(3), 393-408. 
Train, K. (2003). Discrete Choice Methods with Simulation. Cambridge: Cambridge University Press.

Yogo, M. (2016) 'Portfolio Choice in Retirement: Health Risk and the Demand for Annuities, Housing, and Risky Assets.' Journal of Monetary Economics, 80(C), 17-34.

van Rooij, M., Lusardi, A., Alessie, R. (2011) 'Financial literacy and stock market participation.' Journal of Financial Economics, 101(2), 449-472.

Wooldridge, J. M. (2002), Econometric Analysis of Cross-Section and Panel Data. Boston: MIT Press. 


\section{Appendix}

\section{A.1. This study and CDM: How are they different?}

First, CDM studies the decision (as recorded in SHARELIFE) to ever own risky financial assets in the past even for a short period. Such ownership, however, can be due to chance (e.g. because of a received inheritance or gift), or to an impulsive decision that could be soon reversed. In turn, the ownership decisions studied here (as recorded in the first two SHARE waves that are about two years apart) are more likely to be the result of deliberate thought and planning, and thus less likely to be affected by transient factors. This difference becomes clear as one considers that of all the SHARELIFE households that report ever having owned stocks (mutual funds), only 42\% (42\%) own stocks in SHARE wave 1 and only 40\% (33\%) in wave $2{ }^{22}$ And of course, the longer time distance between childhood and the outcomes examined in this paper provides a more stringent test of the continuing relevance of childhood conditions for economic choices in adulthood.

The second reason why the two studies differ is that the variables denoting childhood health problems are different in CDM compared to the current study. In CDM, one of the variables was based on the question on whether respondents had access to a usual source of care (i.e., to a particular person place that they went to when they were sick or needed health advice). The second variable used was self-reported health. Our current study, however, uses a variable denoting spending some time in the hospital, which is (i) an objective indicator of actual health problems that were serious enough to required hospitalization, and also (ii) less likely to suffer from differences in reporting style across individuals.

\footnotetext{
${ }^{22}$ We also note that among SHARELIFE households that report never owning stocks (mutual funds) in their lives, only $4.5 \%$ (4.9\%) report in SHARE waves 1 and 2 that they indeed invest in them. This suggests that the vast majority of households report their asset holdings in a logically consistent manner across all three waves. Therefore, the aforementioned significant divergence reported in asset ownership between waves 1- 2 of SHARE and SHARELIFE is indeed genuine.
} 
Methodologically, CDM uses a simple pooled probit model. Here we allow, in the context of a semi-parametric discrete choice panel model, for autocorrelation in the error terms, which enables us to examine transitions in asset ownership by linking decisions at different points in time. Incorporating the autocorrelation is a novel contribution, allowing us to estimate the transition probabilities and marginal effects without using a lagged dependent variable. It also allows us to avoid having transitions as outcomes, and thus operating with subsamples; instead, we have the usual static choices as outcomes and use the full sample.

Asset ownership transitions are an important topic because they are the outcomes of adjustment decisions that households make close to retirement and influence its financing. The prevalence of such transitions is nontrivial in our sample, especially considering we use survey waves that are only two years apart. CDM could not study such transitions, nor did it separately study bonds, individual retirement accounts (IRAs) and the owned house. The inclusion of bonds is particularly salient as they are the least risky of the assets examined, and thus provide a useful test of the effect of childhood conditions on risk tasking in older age.

\section{A.2. Calculation of Magnitudes of Interest via Monte Carlo Simulation}

The autocorrelation coefficient $\rho$ and the vector of probabilities $\mathbf{p}=\left(p_{2}, \ldots, p_{K}\right)$ must satisfy the following constraints: $\rho$ must lie between minus one and one and $\left(p_{2}, \ldots, p_{K}\right)$ must lie between zero and one. These constraints make convergence of our already complicated likelihood function even more difficult. Therefore, we estimate $\rho$ and $\mathbf{p}$ as functions of the unconstrained parameters $\psi$, and $\boldsymbol{\omega}=\left(\omega_{2}, \ldots, \omega_{K}\right)$, that hence become the ones with respect to which the likelihood function is maximized. The mapping between these new parameters and $\rho$ and $\mathbf{p}$ is as follows: 


$$
\begin{gathered}
\rho=\frac{e^{\psi}-1}{e^{\psi}+1} \\
p_{k}=\frac{e^{\omega_{k}}}{\sum_{k=1}^{K} e^{\omega_{k}}}
\end{gathered}
$$

with $\omega_{1}=0, k=1, \ldots, K$. Given that marginal effects, $\rho$ and $\mathbf{p}$ all represent magnitudes that are nonlinear functions of estimated parameters that are part of $\widehat{\boldsymbol{a}}=$ $\left(\hat{\beta}, \widehat{\psi}, \hat{c}_{2}, \ldots, \hat{c}_{K}, \widehat{\omega}_{2}, \ldots, \widehat{\omega}_{K}\right)$, we compute their point estimates and standard errors via Monte Carlo simulation (Train, 2003), i.e., by using the formula

$$
E(g(\theta))=\int g(\theta) f(\theta) d \theta
$$

where $\theta$ denotes one or more parameters in $\boldsymbol{a}, g(\theta)$ denotes the magnitude of interest and $f(\theta)$ the joint distribution of all the elements in $\theta$. We implement this simulation estimator by drawing 250 times from the joint distribution of the estimated vector of parameters $\hat{a}$ under the assumption that it is asymptotically normal with mean and variance-covariance matrix equal to the maximum likelihood estimates. Then, for a given parameter draw $j$ we generate the magnitude of interest $g\left(\hat{\theta}_{j}\right)$. For marginal effects in particular, we first calculate the partial effect corresponding to each individual in our sample and then calculate the marginal effect $g\left(\hat{\theta}_{j}\right)$ as the weighted average (using sample weights) of the effect across individuals. ${ }^{23} \mathrm{We}$ then estimate $E(g(\theta))$ and its standard error as the mean and standard deviation, respectively, of the distribution of $g\left(\hat{\theta}_{j}\right)$ over all parameter draws.

\footnotetext{
${ }^{23}$ We do not evaluate marginal effects at sample means since this practice can lead to severely misleading results (see Train, 2003, pp. 33-34).
} 
Table 1. Descriptive statistics

\begin{tabular}{|c|c|c|c|c|c|c|c|c|c|c|c|}
\hline Variable & Sweden & Denmark & Germany & Netherlands & Belgium & France & Switzerland & Austria & Italy & Spain & Greece \\
\hline Direct stock ownership & 0.466 & 0.385 & 0.147 & 0.188 & 0.222 & 0.175 & 0.279 & 0.059 & 0.043 & 0.050 & 0.039 \\
\hline Mutual fund ownership & 0.519 & 0.169 & 0.157 & 0.143 & 0.181 & 0.191 & 0.211 & 0.059 & 0.052 & 0.033 & 0.014 \\
\hline Bond ownership & 0.172 & 0.219 & 0.166 & 0.050 & 0.124 & 0.049 & 0.198 & 0.054 & 0.108 & 0.014 & 0.009 \\
\hline IRA ownership & 0.445 & 0.366 & 0.100 &..-- & 0.251 & 0.280 & 0.185 & 0.054 & 0.017 & 0.093 & 0.018 \\
\hline Whole life insurance ownership & 0.363 & 0.244 & 0.322 & 0.274 & 0.232 & 0.176 & 0.213 & 0.283 & 0.065 & 0.080 & 0.024 \\
\hline Ownership of risky assets & 0.796 & 0.623 & 0.299 & 0.273 & 0.429 & 0.469 & 0.435 & 0.144 & 0.094 & 0.149 & 0.065 \\
\hline Willingness to take some financial risk & 0.400 & 0.449 & 0.266 & 0.254 & 0.297 & 0.225 & 0.332 & 0.182 & 0.145 & 0.099 & 0.188 \\
\hline Age & 64.6 & 64.4 & 64.7 & 64.7 & 65.1 & 64.5 & 65.8 & 64.3 & 66.0 & 65.7 & 65.7 \\
\hline In a couple & 0.636 & 0.554 & 0.677 & 0.591 & 0.667 & 0.650 & 0.604 & 0.583 & 0.653 & 0.640 & 0.583 \\
\hline Number of children & 2.24 & 2.13 & 2.05 & 2.28 & 2.13 & 2.28 & 2.10 & 2.16 & 2.10 & 2.49 & 1.85 \\
\hline Self-reported health bad or very bad & 0.335 & 0.339 & 0.534 & 0.417 & 0.403 & 0.457 & 0.318 & 0.464 & 0.635 & 0.598 & 0.407 \\
\hline Number of chronic diseases & 1.76 & 1.94 & 1.86 & 1.52 & 1.98 & 1.86 & 1.29 & 1.65 & 2.19 & 2.12 & 1.74 \\
\hline High school education & 0.254 & 0.387 & 0.496 & 0.259 & 0.258 & 0.330 & 0.429 & 0.402 & 0.170 & 0.095 & 0.225 \\
\hline Post-secondary education & 0.386 & 0.431 & 0.408 & 0.345 & 0.398 & 0.311 & 0.198 & 0.365 & 0.179 & 0.208 & 0.235 \\
\hline Good reading skills & 0.870 & 0.819 & 0.663 & 0.602 & 0.743 & 0.706 & 0.735 & 0.760 & 0.411 & 0.386 & 0.521 \\
\hline Numeracy score & 4.00 & 3.90 & 3.95 & 4.01 & 3.69 & 3.60 & 4.02 & 3.80 & 3.07 & 2.85 & 3.56 \\
\hline Financial wealth (in euros, median) & 23,727 & 16,463 & 15,052 & 18,473 & 19,527 & 12,175 & 37,268 & 6,126 & 3,060 & 1,105 & 0 \\
\hline Real wealth (in euros, median) & 86,618 & 81,406 & 101,557 & 121,254 & 179,323 & 189,491 & 105,818 & 106,333 & 136,253 & 170,185 & 118,551 \\
\hline Household income (in euros, median) & 25,145 & 18,960 & 25,405 & 32,203 & 21,455 & 26,883 & 22,200 & 21,413 & 16,960 & 15,563 & 17,411 \\
\hline $\begin{array}{l}\text { Having more than } 10 \text { books in the } \\
\text { house when } 10 \text { years old }\end{array}$ & 0.838 & 0.826 & 0.759 & 0.737 & 0.640 & 0.616 & 0.773 & 0.644 & 0.265 & 0.430 & 0.410 \\
\hline $\begin{array}{l}\text { Was better than average in math at } \\
\text { school when } 10 \text { years old }\end{array}$ & 0.554 & 0.553 & 0.467 & 0.464 & 0.526 & 0.432 & 0.470 & 0.423 & 0.425 & 0.362 & 0.341 \\
\hline $\begin{array}{l}\text { Was better than average in language at } \\
\text { school when } 10 \text { years old }\end{array}$ & 0.551 & 0.564 & 0.500 & 0.440 & 0.544 & 0.504 & 0.507 & 0.458 & 0.360 & 0.339 & 0.301 \\
\hline $\begin{array}{l}\text { Number of rooms in the house when } 10 \\
\text { years old }\end{array}$ & 4.069 & 4.868 & 4.108 & 4.937 & 5.657 & 4.598 & 5.261 & 3.573 & 3.259 & 3.914 & 2.841 \\
\hline $\begin{array}{l}\text { Spent time in the hospital during } \\
\text { childhood }\end{array}$ & 0.131 & 0.133 & 0.151 & 0.130 & 0.081 & 0.073 & 0.116 & 0.156 & 0.042 & 0.040 & 0.009 \\
\hline Number of households & 1,762 & 1,257 & 1,340 & 1,621 & 2,841 & 1,829 & 764 & 1,106 & 1,740 & 1,432 & 2,462 \\
\hline
\end{tabular}

Notes: All variables are reported at the household-level, with the exception of IRA ownership and the willingness to undertake financial risk, which are measured at the individual level. Magnitudes denoted weighted means, unless otherwised noted. Amounts of net financial wealth, net real wealth and household income are PPP-adjusted. 
Table 2. Tabulations of asset ownership and risk attitudes using measures of childhood SES, cognition and health

\begin{tabular}{|c|c|c|c|c|c|c|c|c|c|c|c|c|c|c|}
\hline \multirow[t]{2}{*}{ Childhood Conditions } & \multicolumn{2}{|c|}{ Stocks } & \multicolumn{2}{|c|}{ Mutual Funds } & \multicolumn{2}{|c|}{$\begin{array}{c}\text { Individual } \\
\text { Retirement } \\
\text { Accounts }\end{array}$} & \multicolumn{2}{|c|}{$\begin{array}{l}\text { Any Risky Financial } \\
\text { Asset }\end{array}$} & \multicolumn{2}{|c|}{ House } & \multicolumn{2}{|c|}{ Bonds } & \multicolumn{2}{|c|}{$\begin{array}{c}\text { Willingness to take } \\
\text { at least some } \\
\text { financial risks }\end{array}$} \\
\hline & Prevalence & td. Err. & Prevalence & Std. Err. & Prevalence & $\overline{\text { Std. Err. }}$ & Prevalence & Std. Err. & Prevalence & $\overline{\text { Std. Err. }}$ & Prevalence & Std. Err. & Prevalence & td. Err. \\
\hline \multicolumn{15}{|c|}{ Had more than ten books in the house } \\
\hline No & 0.0597 & 0.0038 & 0.0627 & 0.0041 & 0.0815 & 0.0031 & 0.1600 & 0.0062 & 0.6679 & 0.0082 & 0.0591 & 0.0042 & 0.1435 & 0.0071 \\
\hline Yes & 0.1898 & 0.0054 & 0.1837 & 0.0055 & 0.1882 & 0.0044 & 0.3774 & 0.0070 & 0.6757 & 0.0071 & 0.1238 & 0.0051 & 0.3015 & 0.0090 \\
\hline \multicolumn{15}{|c|}{$\begin{array}{l}\text { Above median number of rooms in the } \\
\text { house }\end{array}$} \\
\hline No & 0.0924 & 0.0040 & 0.1025 & 0.0046 & 0.1217 & 0.0035 & 0.2297 & 0.0062 & 0.6361 & 0.0074 & 0.0783 & 0.0044 & 0.1884 & 0.0068 \\
\hline Yes & 0.1902 & 0.0062 & 0.1717 & 0.0059 & 0.1674 & 0.0052 & 0.3591 & 0.0078 & 0.7173 & 0.0076 & 0.1204 & 0.0055 & 0.3025 & 0.0111 \\
\hline \multicolumn{15}{|c|}{ Was above average in math at school } \\
\hline No & 0.1020 & 0.0042 & 0.1001 & 0.0045 & 0.1100 & 0.0040 & 0.2246 & 0.0061 & 0.6584 & 0.0073 & 0.0778 & 0.0042 & 0.1876 & 0.0076 \\
\hline Yes & 0.1774 & 0.0060 & 0.1747 & 0.0060 & 0.1679 & 0.0043 & 0.3641 & 0.0078 & 0.6921 & 0.0079 & 0.1209 & 0.0057 & 0.2776 & 0.0091 \\
\hline \multicolumn{15}{|c|}{ Was above average in language at school } \\
\hline No & 0.1097 & 0.0042 & 0.1107 & 0.0043 & 0.0978 & 0.0033 & 0.2417 & 0.0058 & 0.6550 & 0.0068 & 0.0871 & 0.0041 & 0.1964 & 0.0079 \\
\hline Yes & 0.1895 & 0.0068 & 0.1792 & 0.0069 & 0.1842 & 0.0050 & 0.3801 & 0.0090 & 0.7121 & 0.0088 & 0.1177 & 0.0065 & 0.2601 & 0.0087 \\
\hline \multicolumn{15}{|l|}{ Spent time in the hospital } \\
\hline No & 0.1329 & 0.0037 & 0.1276 & 0.0037 & 0.1351 & 0.0030 & 0.2793 & 0.0051 & 0.6786 & 0.0056 & 0.0939 & 0.0036 & 0.2199 & 0.0059 \\
\hline Yes & 0.1583 & 0.0128 & 0.1863 & 0.0147 & 0.1596 & 0.0141 & 0.3570 & 0.0180 & 0.5982 & 0.0192 & 0.1193 & 0.0130 & 0.3161 & 0.0286 \\
\hline
\end{tabular}

Notes: Prevalence of asset ownership and risk attitudes in SHARE waves 1 and 2 shown, calculated using sample weights. The variable denoting number of rooms in the house is a binary one, equal to one if the number is above the median for the given country, and zero otherwise. All variables are measured at the household level, with the exception of IRA ownership and the willingness to undertake financial risk, which are measured at the individual level. 
Table 3. Unconditional (static) marginal effects

\begin{tabular}{|c|c|c|c|c|c|c|c|c|c|c|c|c|c|c|}
\hline \multirow[t]{2}{*}{ Variable } & \multicolumn{2}{|c|}{ Stocks } & \multicolumn{2}{|c|}{ Mutual funds } & \multicolumn{2}{|c|}{$\begin{array}{l}\text { Individual } \\
\text { retirement accounts }\end{array}$} & \multicolumn{2}{|c|}{$\begin{array}{l}\text { All risky financial } \\
\text { assets }\end{array}$} & \multicolumn{2}{|c|}{ House } & \multicolumn{2}{|c|}{ Bonds } & \multicolumn{2}{|c|}{$\begin{array}{c}\text { Willing to take at } \\
\text { least some financial } \\
\text { risk }\end{array}$} \\
\hline & $\begin{array}{c}\text { Marginal } \\
\text { effect }\end{array}$ & Std. error & $\begin{array}{l}\text { Marginal } \\
\text { effect }\end{array}$ & Std. error & $\begin{array}{c}\text { Marginal } \\
\text { effect }\end{array}$ & Std. error & $\begin{array}{l}\text { Marginal } \\
\text { effect }\end{array}$ & Std. error & $\begin{array}{c}\text { Marginal } \\
\text { effect }\end{array}$ & Std. error & $\begin{array}{l}\text { Marginal } \\
\text { effect }\end{array}$ & Std. error & $\begin{array}{c}\text { Marginal } \\
\text { effect }\end{array}$ & Std. error \\
\hline $\begin{array}{l}\text { More than } 10 \text { books in the house } \\
\text { when } 10 \text { years old }\end{array}$ & 0.032 & $0.009 * * *$ & 0.022 & $0.005 * * *$ & 0.015 & $0.005 * * *$ & 0.039 & $0.009 * * *$ & 0.002 & 0.011 & 0.006 & 0.008 & 0.041 & $0.008 * * *$ \\
\hline $\begin{array}{l}\text { Number of rooms in the house when } \\
10 \text { years old }\end{array}$ & 0.002 & 0.002 & 0.001 & 0.001 & 0.000 & 0.001 & 0.001 & 0.002 & 0.011 & $0.002 * * *$ & 0.001 & 0.001 & 0.005 & $0.002 * * *$ \\
\hline $\begin{array}{l}\text { Was better than average at math in } \\
\text { school when } 10 \text { years old }\end{array}$ & 0.033 & $0.008 * * *$ & 0.013 & $0.005 * * *$ & -0.001 & 0.004 & 0.018 & $0.008 * *$ & 0.039 & $0.009 * * *$ & 0.004 & 0.007 & 0.020 & $0.008 * * *$ \\
\hline $\begin{array}{l}\text { Was better than average in language } \\
\text { in school when } 10 \text { years old }\end{array}$ & -0.009 & 0.008 & 0.009 & $0.004 * *$ & 0.007 & 0.004 & 0.011 & 0.008 & -0.010 & 0.010 & 0.001 & 0.006 & 0.004 & 0.008 \\
\hline $\begin{array}{l}\text { Spent time in the hospital during } \\
\text { childhood }\end{array}$ & -0.019 & 0.012 & 0.003 & 0.007 & -0.007 & 0.007 & -0.006 & 0.011 & -0.033 & $0.015 * *$ & -0.008 & 0.013 & 0.011 & 0.013 \\
\hline
\end{tabular}

Notes: Marginal effects denote the change in the relevant ownership probability when the variables of interest change as follows: the binary variables denoting having some books in the house, being above average at math and language at school, and spending time in the hospital during childhood change from zero to one, while the continuous variable denoting the numbers of rooms in the house respondents lived in at age ten changes by one unit. *** denote statistical significance at $1 \%$, ** at $5 \%$, and * at $10 \%$. 
Table 4. Marginal effects on the transition from ownership to non-ownership

\begin{tabular}{|c|c|c|c|c|c|c|c|c|c|c|c|c|}
\hline \multirow{2}{*}{ Variable } & \multicolumn{2}{|c|}{ Stocks } & \multicolumn{2}{|c|}{ Mutual funds } & \multicolumn{2}{|c|}{$\begin{array}{l}\text { Individual } \\
\text { retirement accounts }\end{array}$} & \multicolumn{2}{|c|}{$\begin{array}{l}\text { All risky financial } \\
\text { assets }\end{array}$} & \multicolumn{2}{|c|}{ House } & \multicolumn{2}{|c|}{ Bonds } \\
\hline & $\begin{array}{c}\text { Marginal } \\
\text { effect }\end{array}$ & Std. error & $\begin{array}{c}\text { Marginal } \\
\text { effect }\end{array}$ & Std. error & $\begin{array}{c}\text { Marginal } \\
\text { effect }\end{array}$ & Std. error & $\begin{array}{c}\text { Marginal } \\
\text { effect }\end{array}$ & Std. error & $\begin{array}{c}\text { Marginal } \\
\text { effect }\end{array}$ & Std. error & $\begin{array}{c}\text { Marginal } \\
\text { effect }\end{array}$ & Std. error \\
\hline $\begin{array}{l}\text { More than } 10 \text { books in the house } \\
\text { when } 10 \text { years old }\end{array}$ & -0.033 & $0.008 * * *$ & -0.027 & $0.007 * * *$ & -0.016 & $0.005 * * *$ & -0.034 & $0.010 * * *$ & -0.001 & 0.004 & -0.008 & 0.009 \\
\hline $\begin{array}{l}\text { Number of rooms in the house when } \\
10 \text { years old }\end{array}$ & -0.002 & 0.002 & -0.002 & 0.001 & 0.000 & 0.001 & -0.001 & 0.001 & -0.003 & $0.001 * * *$ & -0.002 & 0.001 \\
\hline $\begin{array}{l}\text { Was better than average at math in } \\
\text { school when } 10 \text { years old }\end{array}$ & -0.034 & $0.008 * * *$ & -0.015 & $0.006 * *$ & 0.001 & 0.004 & -0.016 & $0.007 * *$ & -0.012 & $0.003 * * *$ & -0.005 & 0.007 \\
\hline $\begin{array}{l}\text { Was better than average in language } \\
\text { in school when } 10 \text { years old }\end{array}$ & 0.009 & 0.008 & -0.011 & $0.005 * *$ & -0.007 & 0.004 & -0.010 & 0.007 & 0.003 & 0.003 & -0.002 & 0.007 \\
\hline $\begin{array}{l}\text { Spent time in the hospital during } \\
\text { childhood }\end{array}$ & 0.020 & 0.012 & -0.003 & 0.008 & 0.007 & 0.008 & 0.005 & 0.009 & 0.010 & $0.005 * *$ & 0.009 & 0.013 \\
\hline
\end{tabular}

Notes: Marginal effects denote the change in the relevant choice probability when our variables of interest change as follows: the binary variables denoting having some books in the house, being above average at math and language at school, and spending time in the hospital during childhood change from zero to one, while the continuous variable denoting the numbers of rooms in the house respondents lived in at age ten changes by one unit. 
Table 5. Marginal effects on the transition from non-ownership to ownership

\begin{tabular}{|c|c|c|c|c|c|c|c|c|c|c|c|c|}
\hline \multirow{2}{*}{ Variable } & \multicolumn{2}{|c|}{ Stocks } & \multicolumn{2}{|c|}{ Mutual funds } & \multicolumn{2}{|c|}{$\begin{array}{l}\text { Individual } \\
\text { retirement accounts }\end{array}$} & \multicolumn{2}{|c|}{$\begin{array}{l}\text { All risky financial } \\
\text { assets }\end{array}$} & \multicolumn{2}{|c|}{ House } & \multicolumn{2}{|c|}{ Bonds } \\
\hline & $\begin{array}{c}\text { Marginal } \\
\text { effect }\end{array}$ & Std. error & $\begin{array}{c}\text { Marginal } \\
\text { effect }\end{array}$ & Std. error & $\begin{array}{c}\text { Marginal } \\
\text { effect }\end{array}$ & Std. error & $\begin{array}{c}\text { Marginal } \\
\text { effect }\end{array}$ & Std. error & $\begin{array}{c}\text { Marginal } \\
\text { effect }\end{array}$ & Std. error & $\begin{array}{c}\text { Marginal } \\
\text { effect }\end{array}$ & Std. error \\
\hline $\begin{array}{l}\text { More than } 10 \text { books in the house } \\
\text { when } 10 \text { years old }\end{array}$ & 0.031 & $0.010 * * *$ & 0.015 & $0.003 * * *$ & 0.016 & $0.005 * * *$ & 0.031 & $0.008 * * *$ & 0.001 & 0.005 & 0.005 & 0.008 \\
\hline $\begin{array}{l}\text { Number of rooms in the house when } \\
10 \text { years old }\end{array}$ & 0.002 & 0.002 & 0.001 & 0.001 & 0.000 & 0.001 & 0.001 & 0.001 & 0.005 & $0.001 * * *$ & 0.001 & 0.001 \\
\hline $\begin{array}{l}\text { Was better than average at math in } \\
\text { school when } 10 \text { years old }\end{array}$ & 0.032 & $0.009 * * *$ & 0.009 & $0.003 * * *$ & -0.001 & 0.004 & 0.014 & $0.006 * *$ & 0.016 & $0.005 * * *$ & 0.004 & 0.006 \\
\hline $\begin{array}{l}\text { Was better than average in language } \\
\text { in school when } 10 \text { years old }\end{array}$ & -0.008 & 0.007 & 0.006 & $0.003 * *$ & 0.007 & 0.004 & 0.009 & 0.006 & -0.004 & 0.005 & 0.001 & 0.005 \\
\hline $\begin{array}{l}\text { Spent time in the hospital during } \\
\text { childhood }\end{array}$ & -0.018 & 0.012 & 0.002 & 0.005 & -0.007 & 0.007 & -0.005 & 0.008 & -0.013 & $0.006 * *$ & -0.007 & 0.012 \\
\hline
\end{tabular}

Notes: Marginal effects denote the change in the relevant choice probability when our variables of interest change as follows: the binary variables denoting having some books in the house, being above average at math and language at school, and spending time in the hospital during childhood change from zero to one, while the continuous variable denoting the numbers of rooms in the house respondents lived in at age ten changes by one unit. 
Table A.1A. Regression results for the ownership of stocks, mutual funds, IRAs, and all risky financial assets

\begin{tabular}{|c|c|c|c|c|c|c|c|c|}
\hline \multirow[t]{2}{*}{ Variable } & \multicolumn{2}{|c|}{ Stocks } & \multicolumn{2}{|c|}{ Mutual funds } & \multicolumn{2}{|c|}{$\begin{array}{l}\text { Individual retirement } \\
\text { accounts }\end{array}$} & \multicolumn{2}{|c|}{$\begin{array}{l}\text { All risky financial } \\
\text { assets }\end{array}$} \\
\hline & Coeff. & Std. error & Coeff. & Std. error & Coeff. & Std. error & Coeff. & Std. error \\
\hline Age/100 & -0.596 & $0.351 *$ & 0.236 & 0.281 & -5.493 & $0.406 * * *$ & -1.929 & $0.267 * * *$ \\
\hline Female &..-- &..-- &..-- &..-- & -0.153 & $0.033 * * *$ &..-- &..-- \\
\hline In a couple & 0.279 & $0.072 * * *$ & 0.056 & 0.050 & 0.051 & 0.052 & 0.154 & $0.044 * * *$ \\
\hline Number of children & -0.067 & $0.021 * * *$ & -0.037 & $0.015 * *$ & -0.017 & 0.017 & -0.037 & $0.013 * * *$ \\
\hline Self-reported health bad or very bad & -0.132 & $0.049 * * *$ & -0.169 & $0.041 * * *$ & -0.049 & 0.046 & -0.129 & $0.036 * * *$ \\
\hline Number of chronic health conditions & -0.034 & $0.017 *$ & 0.026 & $0.014 *$ & -0.023 & 0.015 & 0.006 & 0.013 \\
\hline High school education & 0.223 & $0.071 * * *$ & 0.127 & $0.057 * *$ & 0.226 & $0.049 * * *$ & 0.151 & $0.049 * * *$ \\
\hline Post-secondary education & 0.451 & $0.078 * * *$ & 0.374 & $0.058 * * *$ & 0.303 & $0.057 * * *$ & 0.324 & $0.050 * * *$ \\
\hline Good reading skills & 0.203 & $0.062 * * *$ & 0.143 & $0.052 * * *$ & 0.035 & 0.046 & 0.139 & $0.043 * * *$ \\
\hline Has received an inheritance & 0.547 & $0.074 * * *$ & 0.407 & $0.046 * * *$ & 0.272 & $0.039 * * *$ & 0.438 & $0.041 * * *$ \\
\hline Numeracy score & 0.106 & $0.027 * * *$ & 0.088 & $0.022 * * *$ & 0.029 & 0.019 & 0.093 & $0.019 * * *$ \\
\hline Retired & 0.011 & 0.062 & 0.098 & $0.051 *$ & 0.495 & $0.053 * * *$ & 0.216 & $0.046 * * *$ \\
\hline Real wealth (inv. hyp. sine) & 0.076 & $0.010 * * *$ & 0.038 & $0.006 * * *$ & 0.053 & $0.008 * * *$ & 0.052 & $0.005 * * *$ \\
\hline Financial wealth (inv. hyp. sine) & 0.040 & $0.005 * * *$ & 0.030 & $0.003 * * *$ & 0.015 & $0.003 * * *$ & 0.097 & $0.006 * * *$ \\
\hline Non-capital income (inv. hyp. sine) & 0.031 & $0.011 * * *$ & 0.025 & $0.009 * * *$ & -0.001 & 0.008 & 0.012 & $0.007 *$ \\
\hline Time effect for $2^{\text {nd }}$ wave & -0.021 & 0.034 & -0.232 & $0.031 * * *$ & 0.304 & $0.035 * * *$ & 0.016 & 0.026 \\
\hline Country dummy: Denmark & -0.417 & $0.118 * * *$ & -1.465 & $0.106 * * *$ & -0.499 & $0.078 * * *$ & -0.746 & $0.088 * * *$ \\
\hline Country dummy: Germany & -1.760 & $0.186 * * *$ & -1.380 & $0.107 * * *$ & -1.778 & $0.109 * * *$ & -1.837 & $0.103 * * *$ \\
\hline Country dummy: Netherlands & -1.534 & $0.194 * * *$ & -1.538 & $0.105 * * *$ &..-- &..-- & -2.060 & $0.108 * * *$ \\
\hline Country dummy: Belgium & -1.424 & $0.154 * * *$ & -1.436 & $0.111 * * *$ & -0.841 & $0.074 * * *$ & -1.546 & $0.089 * * *$ \\
\hline Country dummy: France & -1.561 & $0.174 * * *$ & -1.185 & $0.098 * * *$ & -0.469 & $0.094 * * *$ & -1.218 & $0.087 * * *$ \\
\hline Country dummy: Switzerland & -0.964 & $0.167 * * *$ & -1.234 & $0.117 * * *$ & -1.579 & $0.112 * * *$ & -1.520 & $0.107 * * *$ \\
\hline Country dummy: Austria & -2.540 & $0.267 * * *$ & -1.987 & $0.134 * * *$ & -2.133 & $0.126 * * *$ & -2.426 & $0.133 * * *$ \\
\hline Country dummy: Italy & -2.387 & $0.250 * * *$ & -1.871 & $0.134 * * *$ & -3.371 & $0.481 * * *$ & -2.591 & $0.135 * * *$ \\
\hline Country dummy: Spain & -2.383 & $0.250 * * *$ & -2.174 & $0.147 * * *$ & -1.674 & $0.127 * * *$ & -2.311 & $0.130 * * *$ \\
\hline Country dummy: Greece & -2.638 & $0.255 * * *$ & -2.769 & $0.139 * * *$ & -3.111 & $0.184 * * *$ & -2.954 & $0.130 * * *$ \\
\hline $\begin{array}{l}\text { More than ten books in the house } \\
\text { when ten years old }\end{array}$ & 0.245 & $0.066 * * *$ & 0.213 & $0.051 * * *$ & 0.152 & $0.047 * * *$ & 0.213 & $0.043 * * *$ \\
\hline $\begin{array}{l}\text { Number of rooms in the house when } \\
\text { ten years old }\end{array}$ & 0.016 & 0.012 & 0.012 & 0.009 & -0.001 & 0.010 & 0.008 & 0.008 \\
\hline $\begin{array}{l}\text { Was better than average at math in } \\
\text { school when ten years old }\end{array}$ & 0.244 & $0.057 * * *$ & 0.123 & $0.045 * * *$ & -0.008 & 0.043 & 0.101 & $0.041 * *$ \\
\hline $\begin{array}{l}\text { Was better than average in language } \\
\text { in school when ten years old }\end{array}$ & -0.064 & 0.057 & 0.086 & $0.046 *$ & 0.000 & $0.000 * * *$ & 0.060 & 0.040 \\
\hline $\begin{array}{l}\text { Spent time in the hospital during } \\
\text { childhood }\end{array}$ & -0.150 & $0.089 *$ & 0.019 & 0.065 & -0.073 & 0.076 & -0.040 & 0.061 \\
\hline Constant & -4.051 & 0.461 & -1.062 & 0.285 & 2.377 & $0.342 * * *$ & -117.114 & 0.350 \\
\hline $\begin{array}{r}\text { Autocorrelation coefficient } \\
\text { Distribution points }\end{array}$ & 0.063 & 0.178 & 0.310 & $0.096 * * *$ & 0.155 & 0.113 & 0.392 & $0.105 * * *$ \\
\hline Point 2 value & 3.559 & $0.425 * * *$ & -1.458 & $0.229 * * *$ & -2.219 & $0.280 * * *$ & 116.436 & $0.138 * * *$ \\
\hline Point 2 probability & 0.241 & $0.050 * * *$ & 0.827 & $0.062 * * *$ & 0.451 & $0.047 * * *$ & 0.878 & $0.295 * * *$ \\
\hline Point 3 value & 1.900 & $0.246 * * *$ &..-- &..-- & 2.709 & $0.221 * * *$ & 117.733 & $0.291 * * *$ \\
\hline Point 3 probability & 0.626 & $0.102 * * *$ &..-- &..-- & 0.280 & $0.024 * * *$ & 0.122 & 0.295 \\
\hline Number of Observations & \multicolumn{2}{|c|}{17,186} & \multicolumn{2}{|c|}{17,166} & \multicolumn{2}{|c|}{24,924} & \multicolumn{2}{|c|}{17,602} \\
\hline
\end{tabular}

Notes: Regression results from panel probit models with autocorrelation. The base country in the set of country binary variables is Sweden. All variables are measured at the household-level, with the exception of IRA ownership, which is measured at the individual level. Standard errors are clustered at the household level. *** denote statistical significance at $1 \%, * *$ at $5 \%$, and $*$ at $10 \%$. 
Table A.1B. Regression results for the ownership of the house, bonds, and for the willingness to undertake some financial risk

\begin{tabular}{|c|c|c|c|c|c|c|}
\hline \multirow[t]{2}{*}{ Variable } & \multicolumn{2}{|c|}{ House } & \multicolumn{2}{|c|}{ Bonds } & \multicolumn{2}{|c|}{$\begin{array}{l}\text { Willing to take at } \\
\text { least some financial } \\
\text { risk }\end{array}$} \\
\hline & Coeff. & Std. error & Coeff. & Std. error & Coeff. & Std. error \\
\hline Age/100 & -0.758 & 0.584 & 1.466 & $0.302 * * *$ & -0.012 & $0.002 * * *$ \\
\hline Female &..-- &..-- &..-- &..-- & -0.303 & $0.027 * * *$ \\
\hline In a couple & 2.157 & $0.131 * * *$ & 0.098 & $0.054 *$ & 0.187 & $0.030 * * *$ \\
\hline Number of children & -0.068 & $0.031 * *$ & -0.046 & $0.016 * * *$ & -0.028 & $0.010 * * *$ \\
\hline Self-reported health bad or very bad & -0.274 & $0.063 * * *$ & -0.150 & $0.046 * * *$ & -0.127 & $0.033 * * *$ \\
\hline Number of chronic health conditions & -0.078 & $0.022 * * *$ & -0.020 & 0.015 & -0.005 & 0.010 \\
\hline High school education & 0.101 & 0.118 & 0.156 & $0.057 * * *$ & 0.138 & $0.033 * * *$ \\
\hline Post-secondary education & 0.233 & $0.122 *$ & 0.346 & $0.062 * * *$ & 0.348 & $0.038 * * *$ \\
\hline Good reading skills & -0.137 & 0.104 & 0.143 & $0.051 * * *$ & 0.074 & $0.030 * *$ \\
\hline Has received an inheritance & 1.136 & $0.108 * * *$ & 0.347 & $0.050 * * *$ & 0.245 & $0.027 * * *$ \\
\hline Numeracy score & 0.068 & $0.032 * *$ & 0.102 & $0.024 * * *$ & -0.670 & $0.073 * * *$ \\
\hline Retired & 0.030 & 0.095 & -0.166 & $0.054 * * *$ & 0.097 & $0.034 * * *$ \\
\hline Real wealth (inv. hyp. sine) & 0.016 & $0.004 * * *$ & 0.031 & $0.006 * * *$ &..-- &..-- \\
\hline Financial wealth (inv. hyp. sine) & -0.080 & $0.006 * * *$ & 0.031 & $0.004 * * *$ &..-- &..-- \\
\hline Non-capital income (inv. hyp. sine) & 0.005 & 0.012 & 0.017 & $0.010 *$ &..-- &..-- \\
\hline Time effect for $2^{\text {nd }}$ wave & 0.017 & 0.037 & -0.087 & $0.033 * * *$ &..-- &..-- \\
\hline Country dummy: Denmark & 0.418 & $0.199 * *$ & 0.149 & 0.100 & 0.057 & 0.054 \\
\hline Country dummy: Germany & 0.379 & $0.203 *$ & -0.104 & 0.105 & -0.298 & $0.059 * * *$ \\
\hline Country dummy: Netherlands & 0.132 & 0.196 & -0.997 & $0.124 * * *$ & -0.397 & $0.057 * * *$ \\
\hline Country dummy: Belgium & 2.402 & $0.200 * * *$ & -0.450 & $0.093 * * *$ & -0.257 & $0.054 * * *$ \\
\hline Country dummy: France & 2.476 & $0.216 * * *$ & -0.979 & $0.123 * * *$ & -0.353 & $0.057 * * *$ \\
\hline Country dummy: Switzerland & -0.554 & $0.227 * *$ & -0.015 & 0.115 & -0.191 & $0.061 * * *$ \\
\hline Country dummy: Austria & 1.031 & $0.210 * * *$ & -0.806 & $0.126 * * *$ & -0.588 & $0.077 * * *$ \\
\hline Country dummy: Italy & 2.577 & $0.231 * * *$ & -0.109 & 0.101 & -0.471 & $0.060 * * *$ \\
\hline Country dummy: Spain & 3.801 & $0.297 * * *$ & -1.272 & $0.161 * * *$ & -0.670 & $0.073 * * *$ \\
\hline Country dummy: Greece & 3.785 & $0.254 * * *$ & -1.548 & $0.149 * * *$ & -0.420 & $0.056 * * *$ \\
\hline $\begin{array}{l}\text { More than ten books in the house } \\
\text { when ten years old }\end{array}$ & 0.017 & 0.110 & 0.060 & 0.052 & 0.154 & $0.030 * * *$ \\
\hline $\begin{array}{l}\text { Number of rooms in the house when } \\
\text { ten years old }\end{array}$ & 0.110 & $0.026 * * *$ & 0.013 & 0.009 & 0.017 & $0.006 * * *$ \\
\hline $\begin{array}{l}\text { Was better than average at math in } \\
\text { school when ten years old }\end{array}$ & 0.415 & $0.106 * * *$ & 0.044 & 0.046 & 0.076 & $0.029 * * *$ \\
\hline $\begin{array}{l}\text { Was better than average in language } \\
\text { in school when ten years old }\end{array}$ & -0.103 & 0.106 & 0.015 & 0.046 & 0.016 & 0.029 \\
\hline $\begin{array}{l}\text { Spent time in the hospital during } \\
\text { childhood }\end{array}$ & -0.346 & $0.147 * *$ & -0.058 & 0.073 & 0.041 & 0.050 \\
\hline Constant & -7.756 & 2.079 & -3.042 & 0.548 & -0.398 & $0.154 * * *$ \\
\hline $\begin{array}{l}\text { Autocorrelation coefficient } \\
\text { Distribution points }\end{array}$ & 0.930 & $0.008 * * *$ & 0.340 & $0.190 *$ &..-- &..-- \\
\hline Point 2 value & 6.756 & $1.889 * * *$ & -1.709 & 1.444 &..-- &..-- \\
\hline Point 2 probability & 1.000 & $0.007 * * *$ & 0.717 & $0.193 * * *$ &..-- &..-- \\
\hline Point 3 value &..-- &..-- &..-- &..-- &..-- &..-- \\
\hline Point 3 probability &..-- &..-- &..-- &..-- &..-- &..-- \\
\hline Number of Observations & & ,602 & & 7,168 & & 647 \\
\hline
\end{tabular}

Notes: Regression results from panel probit models with autocorrelation. The base country in the set of country binary variables is Sweden.All variables are measured at the household-level, with the exception of IRA ownership, which is measured at the individual level. Standard errors are clustered at the household level. *** denote statistical significance at $1 \%, * *$ at $5 \%$, and * at $10 \%$. 